\title{
C-C Motif Chemokine 28
}

National Cancer Institute

\section{Source}

National Cancer Institute. C-C Motif Chemokine 28. NCI Thesaurus. Code C99633.

C-C motif chemokine $28(127 \mathrm{aa}, \sim 14 \mathrm{kDa}$ ) is encoded by the human CCL28 gene. This protein is involved in the mediation of chemotaxis. 